\title{
CHANGES OF FATTY ACID COMPOSITION OF CHLOROBIUM LIMICOLA IMV K-8 CELLS UNDER THE INFLUENCE OF COPPER (II) SULFATE
}

\author{
T. Segin, S. Hnatush, O. Maslovska, O. Vasyliv \\ Ivan Franko National University of Lviv, \\ 4 Hrushevsky Str., Lviv, 79005, Ukraine \\ e-mail:segint@ukr.net
}

\begin{abstract}
Aim. To investigate the changes of fatty acid composition of green sulphur bacteria Chlorobium limicola IMV K-8 cells at the influence of copper (II) sulfate. Methods. Microbiological, biochemical, biometrical. Results. The increase of content of long chain saturated fatty acids of C. limicola IMV K-8 cells, in particular pentadecanoic, hexadecanoic, heptadecanoic and octadecanoic acids was observed under the influence of copper (II) sulfate in concentrations which caused decrease of biomass accumulation up to $70 \%$. Among the first reactions of adaptation of C. limicola IMV K-8 cells under these conditions are cis/trans isomerisation of monounsaturated fatty acids and synthesis of cyclopropane fatty acids. Maintenance of appropriate level of membrane fluidity is provided by branched chain fatty acids. Conclusions. Under the influence of copper (II) sulfate on C. limicola IMV K-8 cells fatty acids composition of membranes is changed, which causes the increase of membranes fluidity, and, probably, is contributed to more efficient efflux of $\mathrm{Cu}^{2+}$ ions.
\end{abstract}

Keywords: green photosynthetic bacteria, Chlorobium limicola, $\mathrm{Cu}^{2+}$ ions, fatty acids.

An increase of anthropogenic influence caused the formation of technogenically transformed territories that occupy large areas. They contain increased amount of organic matters, sulfur compounds and heavy metal ions that affect the vital functions of organisms $[1,2,3]$. Sulfur bacteria, isolated from these territories, could be successfully applied for development of biotechnologies for contaminated environments remediation from organic matter with the simultaneous toxicity neutralization of heavy metal ions and sulfur compounds [4]. Green photosynthetic bacteria Chlorobium limicola take an essential part in functioning of biocenoses of man-made water storages, since it influences carbon and sulfur cycles because of using hydrogen sulfide as the electron donor. It results in $\mathrm{H}_{2} \mathrm{~S}$ elimination from natural water environments [5].

The toxicity of heavy metal ions, in particular ferrum and copper, is caused by their participation in Fenton and Haber-Weiss reactions. It results in reactive oxygen species (ROS) formation. One of the main targets of ROS harmful influence are membranes. It's due to intensification of lipid peroxidation processes and oxidative modification of proteins while bacterial cell damage with free radicals $[6,7,8]$. An important part in bacteria adaptation to the influence of stress factors is caused by the modification of membrane fatty acid composition [9]. Many studies are devoted to investigations the changes of fatty acid composition of bacterial membranes of genera Pseudomonas and 
Vibrio at the influence of toxic organic substances, in particular toluene, xylol, nitrotoluene, 4-chlorophenol etc $[10,11,12,13]$. It has been determined that these microorganisms adapt to the influence of toxic organic compounds because of cis/trans isomerization of monounsaturated fatty acids [14]. The change of the ratio of anteiso-fatty acids to iso-fatty acids was found in Arthrobacter chlorophenolicus bacteria at the influence of high temperatures and various phenol concentrations $[15,16]$. The reactions of synthesis of cyclopropane fatty acids are important for stabilization the membrane of bacteria under stressful environmental conditions [17, 18]. Overexpression of $c f a$ genes of Clostridium acetobutylicum cells causes increase of cyclopropane fatty acids content and resistance to butanol [19]. It is known that changes of degree of saturation of cell lipids due to the influence of toxic compounds are one of the main mechanisms of gram-negative bacteria adaptation at these conditions. An increase of the degree of lipids saturation of Geobacter sulfurreducens bacteria, grown with 2,4-dichlorophenol, benzene, toluene, xylene and ethylbenzene has been determined [20]. There is almost no information according to the influence of heavy metals compounds on fatty acid composition of bacterial lipids with the exception of several studies [20,21, 22]. The investigation [21] describes an increase of the degree of lipids saturation in Klebsiella pneumoniae and Enterobacter intermedius bacteria at the influence of cadmium, nickel, zinc and copper ions.

Green photosynthetic bacteria are often found in the consortia with sulfurreducing bacteria Desulfuromonas acetoxidans [23]. It was established that at the influence of $\mathrm{Fe}$ (III) ions on the membranes of bacteria $D$. acetoxidans IMV B-7384 the unsaturation of cellular lipids decreases and the content of cyclopropane fatty acids and branched chain fatty acids increases. It allows the cell to diminish the probability of cellular lipids damage and maintain an appropriate level of membrane fluidity [22]. The influence of heavy metal ions on the fatty acid composition of photosynthetic bacteria cells, in particular C. limicola, has not been investigated. The determination of adaptation reactions of bacteria isolated from technogenically transformed territories is necessary for understanding the ways of metabolism regulation of microorganisms of aquatic environments contaminated by heavy metal compounds. Therefore, the aim of work was to investigate the changes of fatty acid composition of C. limicola IMV K-8 at the influence of copper (II) sulfate.

Materials and methods. Bacteria Chlorobium limicola IMV K-8, isolated from Yavorivske lake (Lviv region, Ukraine) have been investigated. C. limicola IMB K-8 belongs to the collection of microorganisms of D.K. Zabolotny Institute of Microbiology and Virology of NAS of Ukraine [24]. The bacteria were grown in the GSB cultivation medium which contains g per liter: $\mathrm{KH}_{2} \mathrm{PO}_{4}-0.03 ; \mathrm{NH}_{4} \mathrm{Cl}-0.34 ; \mathrm{KCl}-0.34 ; \mathrm{CaCl}_{2} \times 2 \mathrm{H}_{2} \mathrm{O}-0.15$; $\mathrm{MgSO}_{4} \times 7 \mathrm{H}_{2} \mathrm{O}-0.5$. After sterilization were added $10 \% \mathrm{NaHCO}_{3}-25 \mathrm{ml}$; $\mathrm{Na}_{2} \mathrm{~S} \times 9 \mathrm{H}_{2} \mathrm{O}-5 \mathrm{ml} ; 10 \%$ sodium pyruvate $-10 \mathrm{ml} ; 10 \%$ sodium acetate $10 \mathrm{ml}$; solution of vitamin $\mathrm{B}_{12}\left(2 \mathrm{mg}\right.$ per $100 \mathrm{ml}$ of $\left.\mathrm{H}_{2} \mathrm{O}\right)-1 \mathrm{ml}$; solution of microelements $-1 \mathrm{ml}$. Microelements solution contain per liter: $25 \% \mathrm{HCl}-10$ $\mathrm{ml} ; \mathrm{FeSO}_{4} \times 7 \mathrm{H}_{2} \mathrm{O}-2.0 \mathrm{~g} ; \mathrm{CoCl}_{2} \times 6 \mathrm{H}_{2} \mathrm{O}-190 \mathrm{mg} ; \mathrm{MnCl}_{2} \times 4 \mathrm{H}_{2} \mathrm{O}-100 \mathrm{mg}$; $\mathrm{ZnCl}_{2}-70 \mathrm{mg} ; \mathrm{Na}_{2} \mathrm{MoO}_{4} \times 4 \mathrm{H}_{2} \mathrm{O}-36 \mathrm{mg} ; \mathrm{NiCl}_{2} \times 6 \mathrm{H}_{2} \mathrm{O}-24 \mathrm{mg} ; \mathrm{H}_{3} \mathrm{BO}_{3}-6 \mathrm{mg}$; 
$\mathrm{CuCl}_{2} \times 2 \mathrm{H}_{2} \mathrm{O}-2 \mathrm{mg}$. $\mathrm{pH}$ of medium were 6.7-6.8. Bacteria were cultivated under microaerophilic conditions and constant illumination (wavelength $700-800 \mathrm{~nm}$, intensity $-40 \mathrm{lux}$ ), at a temperature $28{ }^{\circ} \mathrm{C}$ until the exponential phase of growth [5,6]. Microaerophilic conditions have been created by filling the test tubes with medium in the way that exclude the presence of air under the rubber stopper. The oxygen content in the medium was reduced by its rapid cooling after sterilization [25].

For investigation the influence of copper (II) sulfate on fatty acids content of C. limicola IMV K-8, cells were precipitated by centrifugation (3000 g, $60 \mathrm{~min}$ ) in sterile centrifuge tubes and washed with $50 \mathrm{mM}$ Tris- $\mathrm{HCl}$ buffer ( $\mathrm{pH}$ 7.0). The precipitated cells were incubated for one hour in $50 \mathrm{mM}$ Tris- $\mathrm{HCl}$ buffer ( $\mathrm{pH} 7.0$ ) containing copper (II) sulfate in concentration 0.05-0.50 mM. Investigated metal salt was not added into control sample. After incubation bacterial cells were precipitated by centrifugation (3000 g, $60 \mathrm{~min}$ ) in sterile centrifuge tubes, washed with $50 \mathrm{mM}$ Tris-HCl buffer $(\mathrm{pH} \mathrm{7.0)}$ and added into GSB medium (inoculum density was $0.2 \mathrm{~g} / 1$ ). Selected concentrations of copper (II) sulfate cause reduction of biomass accumulation from $10 \%$ to $70 \%$ that allows to estimate the changes of bacterial cells fatty acid composition with the increase of inhibitory effect [6]. On the seventh day of cultivation biomass was precipitated by centrifugation (3000 g, $60 \mathrm{~min}$ ), washed with $50 \mathrm{mM}$ Tris-HCl buffer ( $\mathrm{pH} 7.0$ ), resuspended in a cooled $50 \mathrm{mM}$ Tris- $\mathrm{HCl}$ buffer ( $\mathrm{pH}$ 7.5) and used for obtaining the cell-free extracts. It was achieved by cells destruction with application of the ultrasound homogenizer UZDN$2 \mathrm{~T}\left(22 \mathrm{kHz}, 5 \mathrm{~min}, 0{ }^{\circ} \mathrm{C}\right)$. Extraction of lipids was carried out according to the method described by Bligh and Dyer [26]. After extraction of lipids, the chloroform and methanol mixture was dried on a water bath. $2 \mathrm{ml}$ of hexane was added into the residue and stirred. $0.5 \mathrm{ml}$ of $2 \mathrm{M}$ sodium methylate was added to the mixture, stirred and heated on a water bath $\left(50^{\circ} \mathrm{C}, 5 \mathrm{~min}\right)$. The top layer was taken and filtered through a paper filter. Hexane was dried on a water bath at the temperature $100{ }^{\circ} \mathrm{C}$. Fatty acid methyl esters were dissolved in methanol and analyzed by using a gas chromatograph (Agilent Technologies, USA) with a flame-ionization detector and the capillary column HP-1 (size $50 \mathrm{~m} \times 0.320 \mathrm{~mm}$, Agilent Technologies, USA). The thickness of phase was $1 \mu \mathrm{m}$, the temperature range was $+130 \ldots+250{ }^{\circ} \mathrm{C}$, the temperature gradient was $+4{ }^{\circ} \mathrm{C} / \mathrm{min}$. Helium was used as a gas-carrier. The results were interpreted by using a standard set of methyl esters of bacterial fatty acid (Supelco, USA). The content of separate fatty acids was determined as a percentage of the total peak area. The degree of unsaturation of fatty acids was determined as described in [27].

Statistical analysis of the results was carried out. The main statistical indices of the obtained data (arithmetic mean - M, standard deviation of the arithmetic mean $-m$ ) were calculated. To assess the reliability of the difference between the statistical characteristics of the three alternative sets of data, Student coefficient was counted. The difference was considered reliable when the reliability index $\mathrm{P}$ was $>0.95$ [28]. MS Excel 2003 and Origin 8 were applied for data processing. 
Results. The main fatty acids of $C$. limicola cells IMV K-8 incubated in the medium without copper (II) sulfate, were tetradecanoic (14:0), hexadecanoic (16: 0$)$ and cis-9-hexadecanoic $(16: 1 \omega 9 \mathrm{c})$ acids. These fatty acids form more than $64 \%$ of all fatty acid content of $C$. limicola IMV K-8 cells. Branched chain fatty acids were found in the cells of $C$. limicola IMV K-8. There are 12- and 13-methyltetradecanoic acids (iso-15:0 and anteiso-15:0 respectively), 14-methylpentadecanoic (iso-16:0) and 15-methylhexadecanoic acid (iso-17:0) (Table 1). The presence of fatty acids with straight and branched chains in $C$. limicola IMV K-8 indicates on its probable involvement into the biosynthesis of two synthases (synthetase of branched chain fatty acids and synthetase of straight chain fatty acids), which function independently and use different primers for biosynthesis [29]. Probably, the synthesis of unsaturated fatty acids (16:1 $\omega 9 \mathrm{c}$, cis 18:1 $\omega 9 \mathrm{c}$ and trans 18:1 $\omega 9 \mathrm{c})$ occurs in the anaerobic desaturation path [30].

Table 1 shows the fatty acid composition of two other strains, in particular C. limicola DSM 245 and C. limicola BF8010, according to the results described in [31]. Fatty acids composition of C. limicola IMV K-8 differs from it of C. limicola DSM 245 and C. limicola BF8010. There were identified dodecanoic (12:0), 12-methyltetradecanoic (iso-15:0), 14-methylpentadecanoic

Table 1

Fatty acid composition of $\boldsymbol{C}$. limicola IMV K-8 cells

\begin{tabular}{|c|c|c|c|c|}
\hline Fatty acids & $\begin{array}{l}\text { C. limicola } \\
\text { IMV K-8* }\end{array}$ & $\begin{array}{l}\text { C. limicola } \\
\text { DSM } 245^{* *}\end{array}$ & $\begin{array}{l}\text { C. limicola } \\
\text { BF8010** }\end{array}$ & $\begin{array}{c}\text { The average content for green } \\
\text { photosynthetic bacteria** }\end{array}$ \\
\hline 12:0 & 0.14 & - & - & nd \\
\hline $14: 0$ & 29.49 & 16.61 & 13.00 & $\begin{array}{c}\text { trace quantities - } \\
27.10\end{array}$ \\
\hline 16:0 & 11.18 & 19.93 & 24.25 & $3.52-29$ \\
\hline $18: 0$ & 1.79 & 1.60 & 0.87 & $\begin{array}{c}\text { trace quantities - } \\
3.30 \\
\end{array}$ \\
\hline 15:0 & 0.94 & 14.14 & 9.38 & $2.74-14.14$ \\
\hline $17: 0$ & 0.70 & 0.28 & 0.22 & nd \\
\hline iso-15:0 & 0.72 & - & - & nd \\
\hline anteiso-15:0 & 1.02 & - & 0.48 & nd \\
\hline iso-16:0 & 1.07 & - & - & nd \\
\hline iso-17:0 & 0.31 & - & - & nd \\
\hline anteiso-17:0 & - & - & 0.25 & nd \\
\hline$c y-17: 0$ & 0.46 & - & - & $0.70-21$ \\
\hline 14:1 & - & 0.30 & 0.50 & nd \\
\hline $16: 1 \omega 9 c$ & 23.59 & 38.26 & 41.81 & $37.3-64.0$ \\
\hline cis $18: 1 \omega 9 \mathrm{c}$ & 0.66 & 2.13 & 2.82 & $\begin{array}{c}\text { trace quantities - } \\
15.59\end{array}$ \\
\hline trans $18: 1 \omega 9 \mathrm{c}$ & 5.29 & - & - & nd \\
\hline $14: 2-\mathrm{OH}$ & 0.55 & - & - & nd \\
\hline
\end{tabular}

Note: The content of fatty acids is expressed as the percentage from the total content of fatty acids; * - the error in the three alternative sets did not exceed 5\%; ** - results obtained by analyzing fatty acid methyl esters by gas chromatography and highlighted in the review [31]; "nd" - no data; «-» - fatty acid was not detected. References strains were cultivated in medium which contain $\mathrm{Na}_{2} \mathrm{~S} \times 9 \mathrm{H}_{2} \mathrm{O}$ as electron donor and sodium bicarbonate as carbon donor. 
(iso-16:0), 15-methylhexadecanoic (iso-17: 0 ) and trans-9-octadecanoic (trans 18: $1 \omega 9 \mathrm{c})$ acids in the cells of $C$. limicola IMV K-8 that were not detected in C. limicola DSM 245 and $C$. limicola BF8010. Content of the main fatty acids of $C$. limicola IMV K-8 cells also differs from the content of these fatty acids in the cells of $C$. limicola DSM 245 and $C$. limicola BF8010, as well as from the average content of fatty acids in the cells of green photosynthesis bacteria. It is known that the composition of fatty acids is not only species-specific, but also a strain-specific particularity.

The content of fatty acids depends on the bacterial growth phase and the composition of growth medium [31]. We assume that the composition and the content of fatty acids of $C$. limicola IMV K-8 cells were formed in the process of evolution due to the adaptation of these bacteria to the influence of environmental factors (in particular, heavy metal ions) at the territory of sulfur deposit that was transformed into Yavorivske lake, where this strain was isolated.

For interpretation the effect of copper (II) sulfate on $C$. limicola IMV K-8 bacteria, identified fatty acids were divided into even-numbered saturated fatty acids with, odd-numbered saturated fatty acids, branched chain fatty acids, cyclopropane fatty acids, hydroxy acids and unsaturated fatty acids.

Addition of copper (II) sulfate as a stress factor into the incubation medium of $C$. limicola IMV K-8 caused changes of fatty acid composition in comparison with control. Among even-numbered saturated fatty acids, the content of hexadecanoic and octadecanoic acids changed under the influence of copper (II) sulfate. The content of hexadecanoic acid enhanced while increase of metal salt concentration from 0.05 to $0.25 \mathrm{mM}$.

Hexadecanoic acid content of the cells, which were incubated with $0.5 \mathrm{mM}$ copper (II) sulfate, also exceeded it's value in a control, but decreased by 30 $40 \%$ in comparison with its content at the influence of $0.05-0.25 \mathrm{mM}$ cooper (II) sulfate. The increase of octadecanoic acid content by 2 and 2.4 times was observed for $C$. limicola IMV K-8 cells, incubated in a medium containing $0.05 \mathrm{mM}$ and $0.1 \mathrm{mM}$ copper (II) sulfate respectively. Increase of metal salt concentration in the incubation medium caused that the content of octadecanoic acid either slightly decreased or did not change in comparison with control. The content of dodecanoic acid in bacterial cells, which were incubated in a medium with copper (II) sulfate, did not differ significantly comparing to control. A slight decrease of the tetradecanoic acid content was observed at the influence of all investigated concentrations of copper (II) sulfate (Fig. 1A).

The content of pentadecanoic and heptadecanoic acids in C. limicola IMV K-8 cells increased at the influence of all investigated concentrations of copper (II) sulfate (Fig. 1, B). The highest content of pentadecanoic acid was observed while bacterial cells incubation in the medium with $0.25 \mathrm{mM}$ copper (II) sulfate. The content of pentadecanoic acid increased by $78 \%$ at these conditions. The increase of heptadecanoic acid content depended on the concentration of metal salt in the incubation medium. It increased by 2.6 and 1.9 times at the influence of 0.05 and $0.1 \mathrm{mM}$ copper (II) sulfate respectively. The addition of $0.125-0.5 \mathrm{mM}$ copper (II) sulfate caused a slight increase of heptadecanoic acid content in comparison with control. 

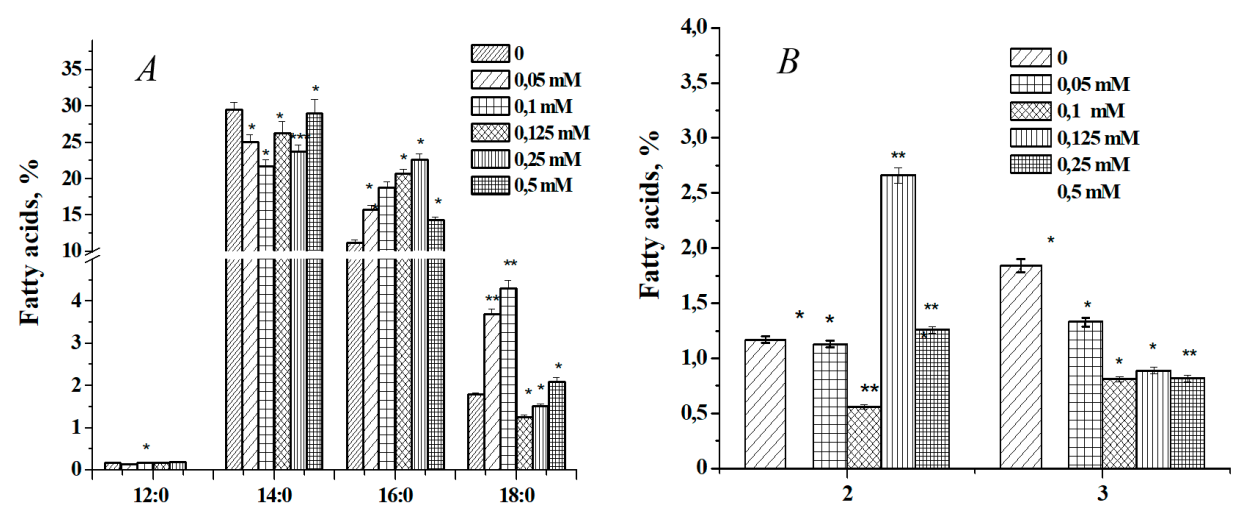

Fig. 1. The content of even-numbered saturated fatty acids (A) and odd-numbered fatty acids (B) of $C$. limicola IMV K-8 cells at the influence of copper (II) sulfate $(*-p \geq 0.95, n=3 ; * *-p \geq 0.99 ; n=3-$ herein and further are reliable changes in comparison with the control)

Consequently, the addition of copper (II) sulfate into the incubation medium causes increase of the content of fatty acids with long carbon chain, in particular pentadecanoic, hexadecanoic and octadecanoic acids, and almost does not change the content of dodecanoic and tetradecanoic acids. It is known that fatty acids with a long carbon chain reduce fluidity of the cytoplasmic membrane [9]. We assume that such changes of fatty acid composition are caused by adaptive response of $C$. limicola IMV K-8 cells to the influence of copper (II) sulfate.

2-hydroxytetradecanoic acid, which belongs to hydroxy acids, was revealed in the cells of C. limicola IMV K-8 (Fig. 2). While bacteria cultivation without addition of copper (II) sulfate the content of 2-hydroxytetradecanoic acid equaled $0.57 \%$ of all cellular fatty acids. At the addition of metal salt into the incubation medium in concentration $0.05-0.1 \mathrm{mM}$ the trace amounts of 2-hydroxytetradecanoic acid were detected. Although at the influence of $0.125-0.5 \mathrm{mM}$ copper (II) sulfate the content of investigated fatty acid increased by 1.3-3.8 times. Hydroxy fatty acids are components of the lipopolysaccharide in the cells of gram-negative bacteria [21]. Probably, due to the effect of copper (II) sulfate the changes of lipopolysaccharide fatty acid composition occurs, and one of such modifications is the change of 2-hydroxytetradecanoic acid content.

Cyclopropane fatty acids are needed to stabilize the bacteria membrane at stress conditions. Synthesis of these fatty acids occurs by binding the methyl group to a double bond in the chain of unsaturated fatty acid. The biophysical properties of cyclopropane fatty acids are similar to those of cis-unsaturated fatty acids, but cyclopropane acids are more resistant to the influence of reactive oxygen species than cis-unsaturated fatty acids [29].

Cis-9,10-methylene hexadecanoic acid, which belongs to the group of cyclopropane fatty acids, was detected in $C$. limicola IMV K-8 cells. Changes of the content of cis-9,10-methylene hexadecanoic acid of C. limicola IMV K-8 cells depended on the concentration of metal salt in the incubation medium. At the addition of $0.05-0.125 \mathrm{mM}$ copper (II) sulfate the increase by $29-45 \%$ 


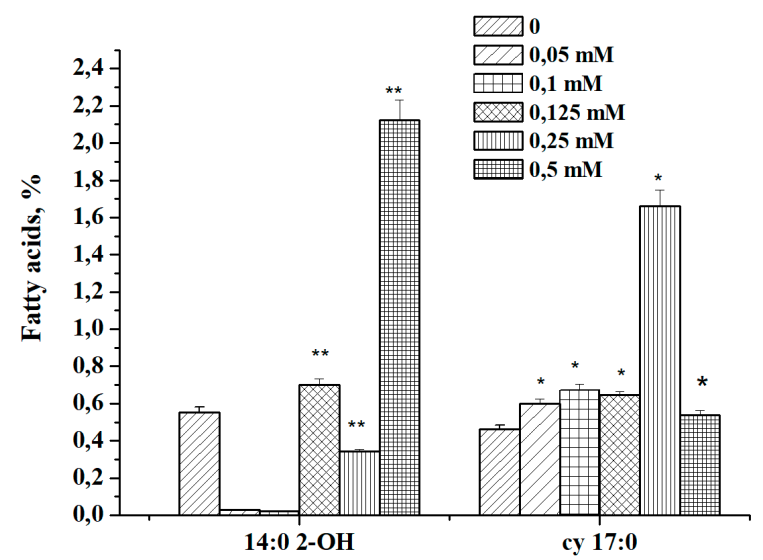

Fig. 2. The content of hydroxy acids (14:0 2OH) and cyclopropane fatty acids (cy 17: 0) in C. limicola IMV K-8 cells at the influence of copper (II) sulfate $(*-p \geq 0.95, n=3 ; * *-p \geq 0.99, n=3)$

of cis-9,10-methylene hexadecanoic acid content was observed in comparison with control. The addition of $0.25 \mathrm{mM}$ copper (II) sulfate into the incubation medium resulted in a 3.6-fold increase of the content of cis-9,10-methylene hexadecanoic acid compared to control.

The predecessor of the synthesis of cis-9,10-methylenehexadecanoic acid is cis-9-hexadecanoic acid [19]. Thus, as the response of C. limicola IMV K-8 bacteria to the influence of copper (II) sulfate the conversion of monounsaturated fatty acids to cyclopropane acids occurs.

Cis-9-hexadecanoic, cis-9-octadecanoic and trans-9-octadecanoic acids, which belongs to the group of unsaturated fatty acids, were identified in C. limicola IMV K-8 cells.

The content of cis-9-hexadecanoic acid in C. limicola IMV K-8 cells increased by $17-45 \%$ at the influence of investigated concentrations of copper (II) sulfate. Cis-9-hexadecanoic acid is one of the main unsaturated fatty acids of gram-negative bacteria, including bacteria of Chlorobium genus. Its content of various representatives of green photosynthesis bacteria is $37.3-64.0 \%$ [31]. We assume that at these conditions there occurs the renovation of membrane lipid composition, which results in the synthesis of cis-9-hexadecanoic acid.

The izomerization of cis-isomers into trans-isomers of unsaturated fatty acids is considered as an alternative way of controlling the fluidity of the cytoplasmic membrane at the influence of toxic compounds [32]. The increase of the cis/trans index at the influence of various stress factors on the cell, such as osmotic stress, heavy metal ions, heat shock and antibiotics, which destroy the membranes, was determined [33, 34, 35]. The double bond in cis-configuration forms the bend of the chain at an angle $30^{\circ}$, which makes impossible the dense packaging of solid phospholipids in the membrane and low phase transition temperature of membrane. Membranes that contain unsaturated fatty acids in cis-configuration are characterized by relatively high fluidity. In contrast, fatty acids in the trans-configuration lose bend in the chain and integrate into the membrane as saturated fatty acids. The isomerization of cis-isomers of unsaturated fatty acids into trans-isomers reduces the fluidity of the cytoplasmic membrane [36]. 
While addition of $0,05-0,25 \mathrm{mM}$ copper (II) sulfate into the incubation medium the content of cis-9-oktadekanoic acid of bacterial cells decreased from $5 \%$ to $71 \%$, with increasing the metal salt concentration in comparison with control (Fig. 3).

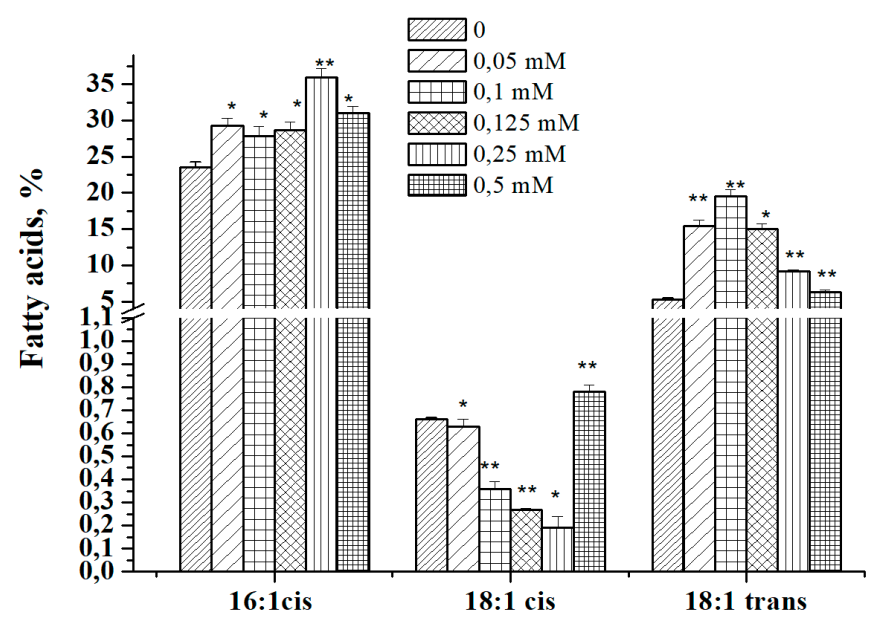

Fig. 3 The content of unsaturated fatty acids in C. limicola IMV K-8 cells at the influence of copper (II) sulfate $(*-p \geq 0.95, n=3 ; * *-p \geq 0.99, n=3$ )

At these conditions the content of trans-9-oktadekanoic acid increases, which probably indicates on cis/trans isomerisation of cis-9-oktadekanoic acid. However, at the influence of $0.5 \mathrm{mM}$ metal salt there was determined a slight increase (18\%) of cis-9-oktadekanoic and trans-9-oktadekanoic acids content. Ferrum-containing enzyme cis/trans-isomerase catalyzes the double-bond isomerization reaction [14]. It is known that enzymes that contain ferrous ions in the active center are susceptible to oxidative damage [37]. In our previous studies, it was found that a significant amount of lipid peroxidation products, which are capable to damage proteins, lipids and nucleic acids, are formed in the cells of C. limicola IMV K-8 at the influence of copper (II) sulfate [6]. We assume that activity of cis/trans isomerase decreased at the influence of $0.5 \mathrm{mM} \mathrm{CuSO}_{4}$ because of its interaction with lipid peroxidation products or as a result of damage of genes responsible for cis/trans isomerase expression by the free radical compounds. Also C. limicola IMV K-8 cells may accumulate copper ions after incubation that initiates new free radical reactions.

Branched chain fatty acids (iso-12 and anteiso-13-methyltetradecanoic acids (iso-15:0 and anteiso-15:0, respectively)) regulate cytoplasmic membrane fluidity in bacterial cells. At the addition of metal salt into the incubation medium, the content of iso-15:0 and anteiso-15:0 acids varied depending on the concentration of metal salt in the medium (Fig. 4). For example, at the influence of $0.05 \mathrm{mM}$ and $0.1 \mathrm{mM}$ copper (II) sulfate, their content was higher in comparison with control. The addition of $0.125 \mathrm{mM}$ and $0.25 \mathrm{mM}$ copper salt caused the decrease of content of iso-15:0 and anteiso-15:0 acids with the increase of metal salt concentration in the medium. At the influence of these concentrations of copper (II) sulfate, the iso-15:0 acid content decreased by $17 \%$ and $71 \%$ respectively. The increase of iso-15:0 and anteiso $-15: 0$ acids 
content by $41 \%$ and $32 \%$ was observed at the addition of $0.5 \mathrm{mM}$ copper (II) sulfate in comparison with control.

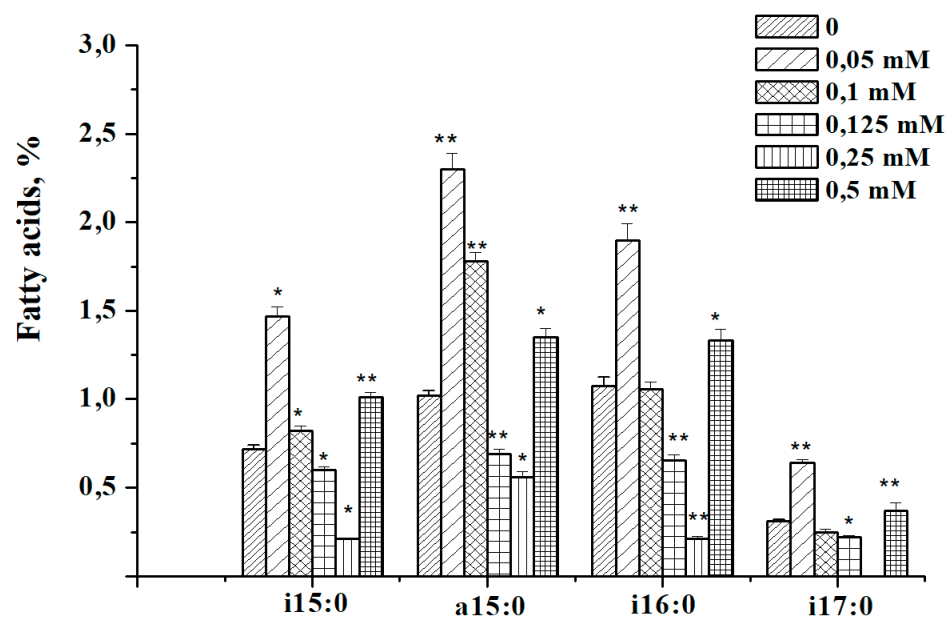

Fig. 4. The content of branched fatty acids of $C$. limicola IMV K-8 cells under the influence of copper (II) sulfate $(*-p \geq 0.95, n=3 * *-p \geq 0.99, n=3$ )

Significant changes of the content of 14-methylpentadecanoic acid (iso-16:0) in bacterial cells at the influence of various concentrations of copper (II) sulfate have been determined in comparison with control. While the addition of $0.05 \mathrm{mM}$ metal salt, the content of this acid increased by $77 \%$ in comparison with control. It is worth to note that under the influence of 0,$1 ; 0.125$ and $0.25 \mathrm{mM}$ copper (II) sulfate, the content of $i s o-16: 0$ decreased in comparison with control. Significant growth (by $24 \%$ ) of 14-methylpentadecanoic acid content was observed while $0.5 \mathrm{mM}$ copper (II) sulfate addition into the growth medium.

In addition to iso-15:0, anteiso-15:0 and iso-16:0 fatty acids of $C$. limicola IMV K-8 cells, the iso-15-methylhexadecanoic acid (iso-17:0) has been investigated. Changes of iso-17:0 acid content of $C$. limicola IMV K-8 cells depended on the concentration of metal salt in the incubation medium. At the influence of $0.05 \mathrm{mM}$ and $0.5 \mathrm{mM}$ copper (II) sulfate the content of iso-17:0 acid increases by $108 \%$ and $21 \%$. While addition of $0.1 \mathrm{mM}$ and $0.125 \mathrm{mM}$ of metal salt the content of investigated fatty acid decreased in comparison with control. Iso-17:0 acid was not detected under the influence of $0.25 \mathrm{mM}$ copper (II) sulfate.

Disscution. Analysis of the results shows that as the response to the influence of copper (II) sulfate on the cells of $C$. limicola IMV K-8 the content of saturated long chain fatty acids, in particular pentadecanoic, hexadecanoic, heptadecanoic and octadecanoic acids increases. Cell adaptation reactions of investigated bacteria to the influence of $\mathrm{Cu}^{2+}$ ions are cis/trans isomerization of monounsaturated fatty acids and the conversion of monounsaturated 
fatty acids into cyclopropane fatty acids. Since cis/trans isomerization and formation of cyclopropane fatty acids occurs post-synthetically, we assume that these reactions are among the first protection mechanisms of $C$. limicola IMV K-8 cells at the influence of $\mathrm{Cu}^{2+}$ ions. However, such changes in fatty acid composition of lipids can lead to the decrease of membrane fluidity. Therefore, investigated bacteria cells synthesize branched chain fatty acids that increase membrane fluidity and possess higher resistance to the influence of reactive oxygen species. Fatty acid composition of $C$. limicola IMV K-8 lipopolysaccharide under the influence of copper (II) sulfate also undergoes changes, which are observed by the increase of 2-hydroxytradecanoic acid content.

Conclusions. As the response of $C$. limicola IMV K-8 cells to the influence of cooper (II) sulfate fatty acid composition of membranes is changed, which causes the increase of membranes fluidity, and, probably, is contributed to more efficient efflux of $\mathrm{Cu}^{2+}$ ions.

\title{
ЗМІНИ ЖИРНОКИСЛОТНОГО СКЛАДУ КЛІТИН CHLOROBIUM LIMICOLA IMB К-8 ЗА ВПЛИВУ КУПРУМ (II) СУЛЬФАТУ
}

\author{
T. Сегін, С. Гнатуш, О. Масловська, О. Василів
}

Львівський національний університет імені Івана Франка вул. Грушевського, 4, Львів 79005, Україна

\section{Резюме}

Мета. Встановити зміни жирнокислотного складу клітин зелених сіркобактерій Chlorobium limicola IMB К-8 за впливу купрум (II) сульфату. Методи. Мікробіологічні, біохімічні, біометричні. Результати. Встановлено зростання вмісту довголанцюгових насичених жирних кислот, зокрема пентадеканової, гексадеканової, гептадеканової і октадеканової, у клітинах C. limicola IMB К-8 за впливу купрум (II) сульфату у концентраціях, які зумовлювали зниження накопичення біомаси до 70 \%. Одними з перших реакцій адаптації клітин $C$. limicola IMB К-8 за цих умов $\epsilon$ цис/ транс ізомеризація мононенасичених жирних кислот і синтез жирних кислот 3 циклопропановим кільцем. Підтримання необхідного рівня текучості мембрани за цих умов забезпечують жирні кислоти з розгалуженим карбоновим ланцюгом. Висновки. Під впливом купрум (II) сульфату на клітини C. limicola IMB К-8 змінюється жирнокислотний склад мембран, що забезпечує зростання їх текучості, та, ймовірно, сприяє більш ефективному викачуванню іонів $\mathrm{Cu}^{2+} 3$ клітини.

Ключові слова: зелені фотосинтезувальні бактерії, Chlorobium limicola, іони $\mathrm{Cu}^{2+}$, жирні кислоти. 


\title{
ИЗМЕНЕНИЯ ЖИРНОКИСЛОТНОГО СОСТАВА КЛЕТОК CHLOROBIUM LIMICOLA ІМВ К-8 ПОД ВЛИЯНИЕМ КУПРУМ (ІІ)СУЛЬФАТА
}

\author{
Т. Сегин, С. Гнатуш, О. Масловская, О. Васылив
}

Львовский национальный университет имени Ивана Франко, ул. Грушевского, 4, Львов 79005, Украина

\section{Резюме}

Цель. Установить изменения жирнокислотного состава клеток зеленых серобактерий Chlorobium limicola ИМВ К-8 под влиянием купрум (II) сульфата. Методы. Микробиологические, биохимические, биометрические. Результаты. Установлено увеличение содержания насыщенных жирных кислот с длинной цепью, в частности пентадекановой, гексадекановой, гептадекановой и октадекановой, в клетках C. limicola ИМВ К-8 под влиянием купрум (II) сульфата в концентрациях, которые повлекли снижение накопления биомассы до 70\%. Одними из первых реакций адаптации клеток C. limicola ИМВ К-8 в этих условиях является цุис/ транс изомеризация мононенасыщенных жирных кислот и синтез жирных кислот с циклопропановым кольцом. Поддержание необходимого уровня текучести мембраны при этих условиях обеспечивают жирные кислоты с разветвленной карбоновой цепью. Выводы. Под влиянием купрум (II) сульфата на клетки C. limicola ИМВ К-8 меняется жирнокислотный состав мембран, что обеспечивает возрастание их текучести, и, вероятно, способствует более эффективному выкачиванию ионов $\mathrm{Cu}^{2+}$ из клетки.

Ключевые слова: зеленые фотосинтезирующие бактерии, Chlorobium limicola, ионы $\mathrm{Cu}^{2+}$, жирные кислоты.

1. Moroz O, Yavorska H, Muravel N, Klym I. [Reduction of ferrum (III) by sulfate reducing and sulfur reducing bacteria]. Studia biologica. 2012; 6(2):161-172. Ukrainian.

2. Karpinets L, Lobachevska O, Baranov V, Diakiv S, Hnatush S. [Total content of nitrogen and heavy metals in the mosses gametophyte and in upper layer of technogenic substrates of the mine dumps]. Studia biologica. 2017; 11(1):101-108. Ukrainian.

3. Mamatha M, Aravinda H, Puttaiah E, Manjappa S. Adsorption of ferrous and ferric ions in aqueous and industrial effluent onto Pongamia pinnata tree bark. Int. J. Chem. Mol. Nucl. Mater. Metallurg. 2012; 6(7):43-51.

4. Moroz OM, Hudz SP, Podopryhora OI et al. [Heavy methals influence on growth and sulfate reduction of Desulfovibrio desulfuricans]. Sci. Bull. Uzhgorod Univ. (Ser. Biol.). 2009; 26:193-202. Ukrainian.

5. Gorishnyi MB, Hudz SP, Hnatush SO. [Bacterial photosynthesis]. Lviv: Publishing center of Ivan Franko National University of Lviv; 2011. Ukrainian.

6. Sehin TB, Hnatush SO, Gorishnyi MB. [The processes of lipid peroxidation in the cells of Chlorobium limicola IMV K-8 under the influence of copper (II) sulfate]. Visn. Dnipropetr. Univ. Ser. Biol. Ekol. 2016; 24(1):72-77. Ukrainian.

7. Gueraud F, Atalay M, Bresgen N, et al. Chemistry and biochemistry of lipid peroxidation products. Free Rad. Res. 2010; 44(10):1098-1124. 
8. Stadtman E, Levine R. Free radical-mediated oxidation of free amino acids and amino acid residues in proteins. Amino Acids. 2003; 25:207-218.

9. Baysse C, O'Gara F. Role of membrane structure during stress signaling and adaptation in Pseudomonas. In: Ramos J, Filloux A, editors. Pseudomonas. New York: Springer; 2007. p. 193-224.

10. Loffhagen N, Hartig C, Babel W. Pseudomonas putida NCTC 10936 balances membrane fluidity in response to physical and chemical stress by changing the saturation degree and the trans/cis ratio of fatty acids. Biosci. Biotechnol. Biochem. 2004; 68(4):317-323.

11. Hartig C, Loffhagen N, Harms H. Formation of trans fatty acids is not involved in growth-linked membrane adaptation of Pseudomonas putida. App. Environ. Microbiol. 2005; 71(4):1915-1922.

12. Heipieper H, Diefenbach R, Kewelon H. Conversion of cis unsaturated fatty acids to trans, a possible mechanism for the protection of phenol-degrading Pseudomonas putida P8 from substrate toxicity. Appl. Env. Microbiol. 1992; 58(6):1847-1852.

13. Mrozik A, Piotrowska-Seget Z, Labuzek S. Changes in whole cell-derived fatty acids induced by naphthalene in bacteria from genus Pseudomonas. Microbiol. Res. 2004; 159:87-95.

14. Heipieper H, Meinhardt F, Segura A. The cis-trans isomerase of unsaturated fatty acids in Pseudomonas and Vibrio: biochemistry, molecular biology and physiological function of a unique stress adaptive mechanism. FEMS Microbiol. Lett. 2003; 229:1-7.

15. Murinova S, Dercova K. Response mechanisms of bacterial degraders to environmental contaminants on the level of cell walls and cytoplasmic membrane. Int. J. Microbiol. 2014; 2014:1-16.

16. Unell M, Kabelitz N, Jansson J, Heipieper H. Adaptation of the psychrotroph Arthrobacter chlorophenolicus A6 to growth temperature and the presence of phenols by changes in the anteiso/iso ratio of branched fatty acids. FEMS Microbiol. Lett. 2007; 266:138-143.

17. Poger D. A ring to rule them all: the effect of cyclopropane fatty acids on the fluidity of lipid bilayers. J. Phys. Chem. B. 2015; 119(17):5487-5495.

18. Ramos J, Cuenca M, Molina-Santiago C, et al. Mechanisms of solvent resistance mediated by interplay of cellular factors in Pseudomonas putida. FEMS Microbiol. Rev. 2015; 39(4):555-566.

19. Grogan D, Cronan J. Cyclopropane ring formation in membrane lipids of bacteria. Microbiol. Mol. Biol. Rev. 1997; 61(4):429-441.

20. Duldhardt I, Gaebel J, Chrzanowski L, et al. Adaptation of anaerobically grown Thauera aromatica, Geobacter sulfurreducens and Desulfococcus multivorans to organic solvents on the level of membrane fatty acid composition. Microbial Biotechnol. 2010; 3(2):201-209.

21. Markowicz A, Plociniczak T, Piotrowska-Seget Z. Response of bacteria to heavy metals measured as changes in FAME profiles. Pol. J. Environ. Stud. 2010; 19(5):957-965.

22. Maslovska OD, Hnatush SO, Halushka AA. [Fatty acid composition of Desulfuromonas acetoxidans IMV B-7384 cells under the influence of ferric citrate]. Studia biologica. 2014; 8(3-4):87-98. Ukrainian.

23. Biebl H, Pfennig N. Growth of sulfate-reducing bacteria with sulfur as electron acceptor. Arch. Microbiol. 1977; 112:115-117. 
24. Hnatush S, Goryshnyi M, Segin T. [Photosynthetic green sulfur bacteria, isolated from Yavoriv lake] Inter-medykal. J. 2014; 3:63-68. Russian.

25. Rozanova EP. Metodyi kultivirovaniya i identifikatsii anaerobnyih bakteriy, vosstanavlivayuschih seru i eyo okislennyie soedineniya. Moskva: Institut mikrobiologii AN SSSR; 1979. Russian.

26. Bligh E, Dyer W. A rapid method for total lipid extraction and purification. Can. J. Biochem. Physiol. 1959; 37:911-917.

27. Guerzoni M, Lanciotti R, Cocconcelli P. Alteration in cellular fatty acid composition as a response to salt, acid, oxidative and thermal stresses in Lactobacillus helveticus. Microbiology. 2001; 147:2255-2264.

28. Lakin GF. Biometriya. Moskva: Vyissh. Shkola;1990. Russian.

29. Kaneda T. Iso- and anteiso-fatty acids in bacteria: biosynthesis, function, and taxonomic significance. Microbiol. Rev. 1991; 55(2):288-302.

30. Zhang Y. Transcriptional regulation in bacterial membrane lipid synthesis. J. Lipid Res. 2009; 50:115-119.

31. Núñez-Cardona MT. Fatty acids analysis of photosynthetic sulfur bacteria by gas chromatography. In: Bekir S, editor. Gas Chromatography - biochemicals, narcotics and essential oils. InTech; 2012. p. 118-138.

32. Guckert JB, Hood MA, White DC. Phospholipid ester-linked fatty acid profile changes during nutrient deprivation of Vibrio cholerae: increases in the trans/cis ratio and proportions of cyclopropyl fatty acids. Appl. Environ. Microbiol. 1986; 52:794-801.

33. Doreswamy K, Shrilatha B, Rajeshkumar T, Muralidhara H. Nickel induced oxidative stress in testis of mice: evidence of DNA damage and genotoxic effects. J. Androl. 2004; 25(6):996-1003.

34. Frostegard A, Tunlid A, Baath E. Changes in microbial community structure during long-term incubation in two soils experimentally contaminated with metals. Soil Biol. Biochem. 1996; 28:55-63.

35. Li Y, Trush M. DNA damage resulting from the oxidation of hydroquinone by copper: role for a $\mathrm{Cu}[\mathrm{II}] / \mathrm{Cu}[\mathrm{I}]$ redox cycle and reactive oxygen generation. Carcinogenesis. 1993; 14(7):1303-1311.

36. Zhang Y. Membrane lipid homeostasis in bacteria. Nat. Rev. Microbiol. 2008; 6:222233.

37. Berlett B, Stadtman E. Protein oxidation in aging, disease, and oxidative stress. J. Biol. Chem. 1997; 272(33):20313-20316.

Отримано 15.11.2017 